腎細胞癌に対する腎摘出術術式と放射線

療法および化学療法併用の評価

\author{
増 田富士男 \\ 町明豊平 \\ 東京慈恵会医科大学泌尿器科学教室 佐 々 木 忠 正
(主任: 町田豊平教授) \\ （主任：町田豊平教授）菱沼秀雄 \\ 荒井间和

\section{EVALUATION OF RADIATION THERAPY AND CHEMOTHERAPY COMBINED WITH NEPHRECTOMY FOR RENAL CELL CARCINOMA}

\author{
Fujio Masuda, Toyohei Machida, Tadamasa Sasaki, Hideo Hishinuma and \\ Yoshikazu Arai \\ Department of Urology, The Jikei University School of Medicine, Tokyo \\ (Director: Prof. T. Machida)
}

The survival rates were studied in 82 patients with renal cell carcinoma comparing nephrectomy alone to nephrectomy combined with radiation therapy and/or chemotherapy.

The 3 -year and 5 -year survival rates of all 82 patients were $44 \%$ and $39 \%$, respectively.

In 69 patients capable of undergoing nephrectomy of these 82 patients, the 3 -year and 5 -year survival rates were $50 \%$ and $46 \%$, respectively. Surgical procedures in these 69 patients undergoing nephrectomy were transperitoneal nephrectomy in 47 patients, translumbar nephrectomy in 20 patients and thracoabdominal nephrectomy in 2 patients. Examining the relationship between surgical procedures and survival rates in 33 patients with stages II and III to which surgical procedures were considered to be important, the survival rate of 25 patients undergoing transperitoneal nephrectomy was more favorable in comparison with that of 8 patients undergoing translumbar nephrectomy up to 2 years after operation, but no difference was found between both surgical procedures after 3 years or thereafter.

Of 65 patients undergoing nephrectomy and survived more than 2 months after operation, 44 patients received radiation therapy and 38 patients received chemotherapy. And, 28 of these patients received both radiation therapy and chemotherapy.

31 patients received 4,000-6,000 rads postoperatively and 13 patients received 3,000-4,000 rads preoperatively. The survival rate of these 44 patients were apparently favorable compared with that of 21 patients who received no radiation therapy, and its favorable effect was more prominent in patients with stages II and III.

However, the survival rate was not improved further even if chemotherapy was further added. As chemotherapy, first 3 cases were administered $5-10 \mathrm{mg}$ of thio-Tepa, 10-20 times, 10 patients $2-4 \mathrm{mg}$ of mitomycin C 10-20 times, and the rest 25 patients $2-4 \mathrm{mg}$ of mitomycin, $250-500 \mathrm{mg}$ of 5 -fluorouracil and 20 $40 \mathrm{mg}$ of cytosine arabinoside twice a week, totally 10 times after operation.

The survival rate of these 38 patients who received chemotherapy was similar to that of 27 patients who received no chemotherapy. No improvement of the survival rate due to chemotherapy was obtained in patients at every stage.

\section{緒言}

腎腫瘍は泌尿器科領域における悪性腫瘍のなかでは,
膀朕腫瘍, 前立腺癌についで多い. 特に腎細胞癌は臨床 的に早期診断がつけにくく，予後も不良である. 
一般に腎細胞癌の予後を支配する 因子としては，1） 性別, 患側, 2) 症状とその持続期間, 3) 腫瘍の大き さ，4）細胞型，5）組織学的悪性度，6）静脈への浸 潤，7） staging，8）治療法などがあげられる.

われわれはこれまで, 慈恵医大泌尿器科学教室で経験 した腎細胞癌について，種々の観点から報告してきた が, 今回はその治療法と生存率, とくに腎摘出術術式と 放射線療法抢よび化学療法併用の効果について検討した ので, 文献的考察を加光て報告する.

\section{対}

慈恵医大附属病院で, 1953年 1 月より1975年 3 月まで の 22 年 3 カ月間に 経験した 82 例の腎細胞癌を対象とし た。

82例の性別は男子65例, 女子17例と男子は女子の 3.8 倍であり, 患側は左43例, 右39例と特に左右差はなかつ た。年齢は29墄から76歳までであつたが，50歳台が41例 と半数を占め, 平均年齢は 56 歳であつた.

腎細胞癌の stage について，われわれは Robson の 分類 ${ }^{1}$ を参考にし，次のごとく stage I からIVに分類し た. stage I は腫瘍が被膜内に限局するもの, Stage II は腎周囲脂肪織へ浸潤するもの, stage III腎静脈内一 の浸潤または所属りンパ節に転移のあるもの, stage IV は遠隔転移のあるものである.この分類により82例の stage をみると, stage I は28例 (34\%), stage II は24 例 (29\%), stage III は15例 (18\%), stage IVは15例 (18 \%)であつた.

また生存率については，1963年 international symposium on end result of cancer therapy で採用された生 存率の計算法に準じて, 実測生存率を算出した。

\section{治療成繶}

全 82 例の転帰をみると，1 年生存率 $65 \% ， 3$ 年生存率 $44 \%, 5$ 年生存率 $39 \%$ であつた（図 1 ).

つぎに腎摘出術の有無拉よび手術術式と生存率, 放射 線療法ならびに化学療法併用の効果について検討した。

1. 腎摘出術

1）腎摘出術施行の有無と生存率

82例中腎摘出術を行なつたものは69例で, その 3 年生 存率は $50 \%, 5$ 年生存率は $46 \%$ であつた. 一方非腎摘出 例は13例で, 進行度は stage IIIが 5 例, stage IVが 7 例 と high stage が大部分であつたが，その 3 年生存率は $15 \%$ とははなだ不良で, 5 年生存例はみられなかつた (表 1 , 図 2).

腎摘出術を行なつた69例中, 術後合併症で 1 力月以内
図 1 全82例の生存率

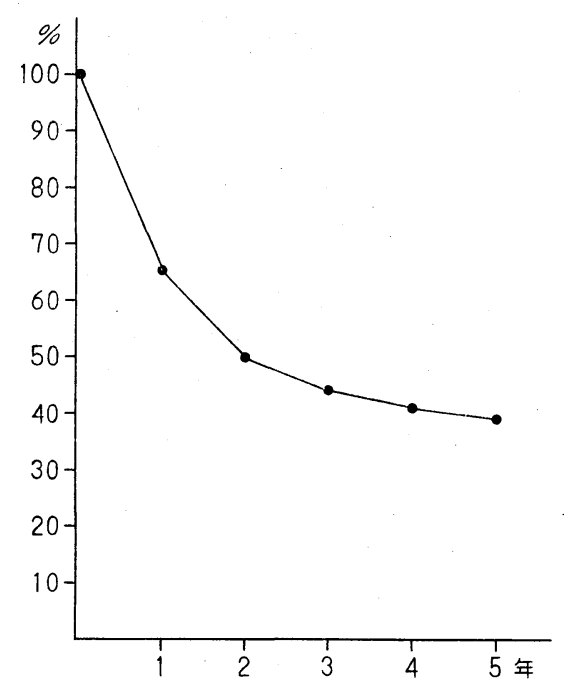

表 1 腎摘出術施行の有無と生存率 (\%)

\begin{tabular}{c|c|c|c|c|c}
\hline & 1 年 & 2 年 & 3 年 & 4 年 & 5 年 \\
\hline 堅摘出術 $(+)$ & 70 & 56 & 50 & 49 & 46 \\
\hline 腎摘出術(-) & 39 & 23 & 15 & 5 & \\
\hline
\end{tabular}

図 2 腎摘出術施行の有無之生存率

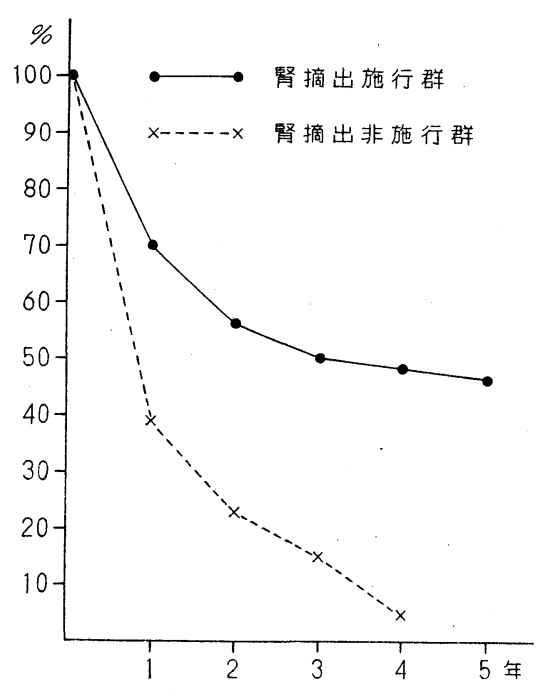

に死亡したものは 3 例で, 手術による死亡率は $4.3 \%$ で あつた。

2）腎摘出術術式と生存率

腎細胞癌の手術術式について，われわれは出来るだけ 早く,腎の剥離を行なら前に腎茎血管を処置することが 
大切と考え，経腹膜式腎摘出術を多く行なつており，腎 摘出69例中 47 例 $(68 \%)$ に本法を施行している。また経 腰式腎摘出術を行なつたものは20例 (29\%), 経胸腹式 腎摘出術は 2 例であつた（表 2 ）.

表 2 腎摘出術術式

\begin{tabular}{c|c}
\hline \multicolumn{1}{c|}{ 手術術式 } & 例 数 \\
\hline 経腹膜式腎摘出術 & $47(68 \%)$ \\
\hline 経腰式腎摘出術 & $20(2996)$ \\
\hline 経胸腹式留摘出術 & 2 \\
\hline
\end{tabular}

経胸腹式腎摘出術を施行した 2 例は，術後 3 年 7 カ月 扣よび 2 年 1 力月の現在, 再発転移なく健在であるが, 2 例のみではこれを他の術式施行群の成績と比較検討寸 ることは無理である。そこでつぎに経腹膜式腎摘出術を 行なつた 47 例と，経腰式腎摘出術を施行した 20 例とにつ いて生存率を比較すると，1 年生存率は $69 \%$ および68\% と差を認めないが， 3 年打よび 5 年生存率は経腰式腎摘 出群がともに $62 \%$ であるのに対し，経腹膜式腎摘出群は それぞれ $43 \% ， 36 \%$ と，経腰式腎摘出の方がむしろ良好 な成績を示した（表 3，図3）。

表 3 腎摘出術術式と生存率（\%)

\begin{tabular}{c|c|c|c|c|c}
\hline & 1 年 & 2 年 & 3 年 & 4 年 & 5 年 \\
\hline 経腹膜式 & 69 & 51 & 43 & 40 & 36 \\
\hline 経 腰 式 & 68 & 62 & 62 & 62 & 62 \\
\hline
\end{tabular}

因 3 腎摘出術術式と生存率

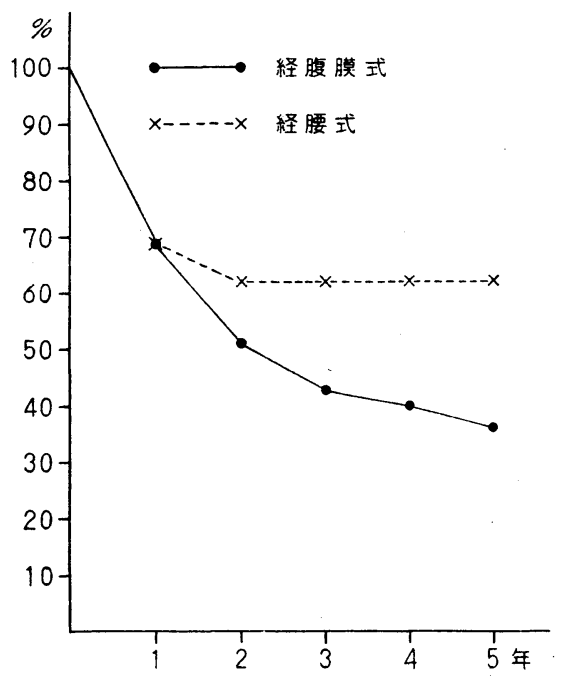

表 4 腎摘出術術式と stage 別例数

\begin{tabular}{c|c|c|c|c}
\hline & I & II & III & IV \\
\hline 経腹膜式 & $\begin{array}{c}15 \\
(32 \%)\end{array}$ & $\begin{array}{c}17 \\
(36 \%)\end{array}$ & $\begin{array}{c}8 \\
(17 \%)\end{array}$ & $\begin{array}{c}7 \\
(15 \%)\end{array}$ \\
\hline 経 腰 式 & $\begin{array}{c}12 \\
(60 \%)\end{array}$ & $\begin{array}{c}6 \\
(30 \%)\end{array}$ & $\begin{array}{c}2 \\
(10 \%)\end{array}$ & 0 \\
\hline
\end{tabular}

そこで両群の症例を stage 別に分類してみると表 4 のごとくで，経腰式腎摘出群には stage IVの例がなく， 且つ stage I の症例が非常に多いことが，予後に大きく 関与している可能性が考兄られた。したがつてつぎに， 手術術式が最も問題となると思われる stage II および III の33例について生存率を比較すると, 術後 3 年以後は両 者に差を認めないが， 1 年拈よび 2 年生存率は経腰式腎 摘出群が $43 \%$ であるのに対し，経腹膜式腎摘出例は76\% および $56 \%$ ， 経腹膜式腎摘出群の方が 良好であつた (表 5 , 図 4).

2. 放射線療法抢よび化学療法

腎摘出術に併用した放射線療法および化学療法の効果 について検討した。

腎摘出術を行ない，術後 2 カ月以上生存した65例中，

表 5 stage II, III 症例に打忊る腎摘出術術式と生 存率 $(\%)$

\begin{tabular}{c|c|c|c|c|c}
\hline & 1 年 & 2 年 & 3 年 & 4 年 & 5 年 \\
\hline 経腹膜式 & 76 & 56 & 45 & 39 & 39 \\
\hline 経 腰 式 & 43 & 43 & 43 & 43 & 43 \\
\hline
\end{tabular}

因 4 stage II， II の症例に怙ける腎摘出術術式と生 存率

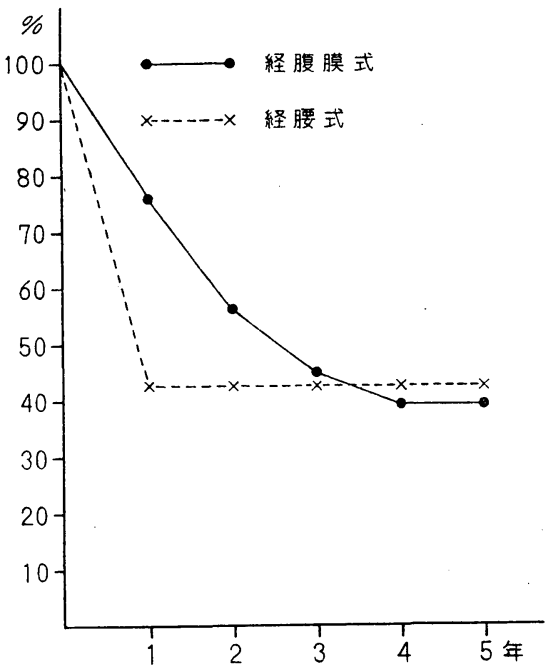


表 6 腎摘出例における放射線療法および化学療法 併用例数

\begin{tabular}{c|c|c|c} 
& 化学療法(+) & 化学療法(-) & 計 \\
\hline 放射線療法(+) & 28 & 16 & 44 \\
\hline 放射線療法(-) & 10 & 11 & 21 \\
\hline 計 & 38 & 27 & 65 \\
\hline
\end{tabular}

手術と同時に放射線療法を施行した症例は44例, 化学療 法を併用したものは38例であり，それらのうち28例は放 射線療法, 化学療法の両者を併用している (表 6 ).

放射線療法としては，44例中 31 例飞 4,000 6,000 rads の術後照射を，13例には3,000〜4,000 rads の術前照射を 行なつている。また化学療法としては, 初期の 3 例には thio-Tepa 5〜10mg を10〜20回，10例には mitomycin C 2〜4mg を10〜20回投与したが，その後の 25例には MFC 療法, すなわち mitomycin C 2〜4mg, 5-fluorouracil $250 \sim 500 \mathrm{mg}$, cytosine arabinoside $20 \sim 40 \mathrm{mg}$ の三 剂を手術後より週 2 回, 合計 10 回投与している。

1）放射線療法併用と生存率

腎摘出術に放射線療法を併用した44例の生存率は 1 年 $84 \% ， 3$ 年括よび 5 年はともに $61 \%$ と, 非併用群 21 例の

表 7 放射線療法併用の有無之生存率（\%)

\begin{tabular}{c|c|c|c|c|c}
\hline & 1 年 & 2 年 & 3 年 & 4 年 & 5 年 \\
\hline 放射線療法(+) & 84 & 64 & 61 & 61 & 61 \\
\hline 放射線療法(-) & 56 & 51 & 39 & 32 & 26 \\
\hline
\end{tabular}

図 5 放射線療法併用の有無と生存率

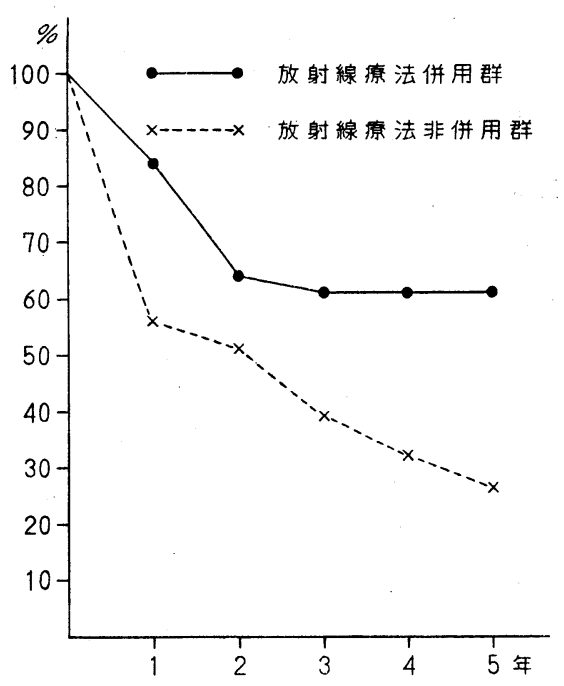

1 年生存率 $56 \% ， 3$ 年生存率 $39 \% ， 5$ 年生存率 $26 \%$ より はるかによい成績を示している（表 7, 図5）.

な打放射線療法を併用した44例中28例は，化学療法も 同時に施行しているので, 上記の成績を検討する際, こ の点を加味して生存率を考える必要がある。そこで放射 線療法施行例44例について, 化学療法併用の有無により 生存率を比較すると, 化学療法も併用した 28 例の 1 年生 存率は $82 \%, 3$ 年および 5 年生存率は $59 \%$ であるのに対 し，非併用群もそれぞれ $87 \% ， 64 \%$ とほぼ同様の成績 で, 化学療法併用の効果は認められなかつた（表 8 , 図 $6)$.

表 8 放射線療法併用群に招ける化学療法施行の有 無と生存率 $(\%)$

\begin{tabular}{c|c|c|c|c|c}
\hline & 1 年 & 2 年 & 3 年 & 4 年 & 5 年 \\
\hline 化学療法(+) & 82 & 64 & 59 & 59 & 59 \\
\hline 化学療法(-) & 87 & 64 & 64 & 64 & 64 \\
\hline
\end{tabular}

図 6 放射線療法併用群における化学療法施行の有 無と生存率

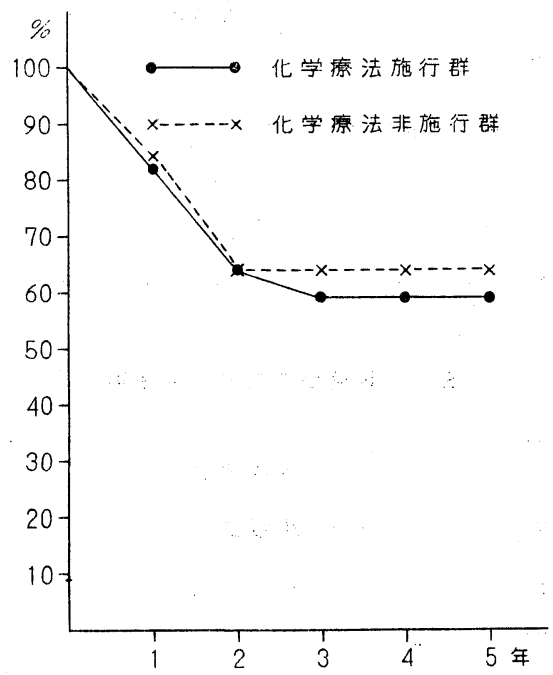

つぎにこの 放射線療法併用の効果を stage 別にみる ために，65例を stage ごとに放射線療法併用例と非併 用例とに分けて検討した. stage I の27例では, 併用群 22 例の 1 年, 3 年および 5 年生存率は $91 \%, 71 \%, 64 \%$, 非併用群 5 例のそれは $80 \% ， 80 \% ， 53 \%$ と明らかな差は なかつた（表 9 ，図 7).これに対し stage II および吕 の症例31例では, 放射線療法併用21例の 1 年生存率は 81 $\%, 3$ 年生存率 $53 \%, 5$ 年生存率 $53 \%$, , 非併用群 10 例 
表 9 stage I の症例における放射線療法併用の有 無之生存率 $(\%)$

\begin{tabular}{c|c|c|c|c|c}
\hline & 1 年 & 2 年 & 3 年 & 4 年 & 5 年 \\
\hline 放射線療法 $(+)$ & 91 & 71 & 71 & 71 & 64 \\
\hline 放射線療法 $(-)$ & 80 & 80 & 80 & 80 & 53 \\
\hline
\end{tabular}

図 7 stage I の症例における放射線療法併用の有 無と生存率

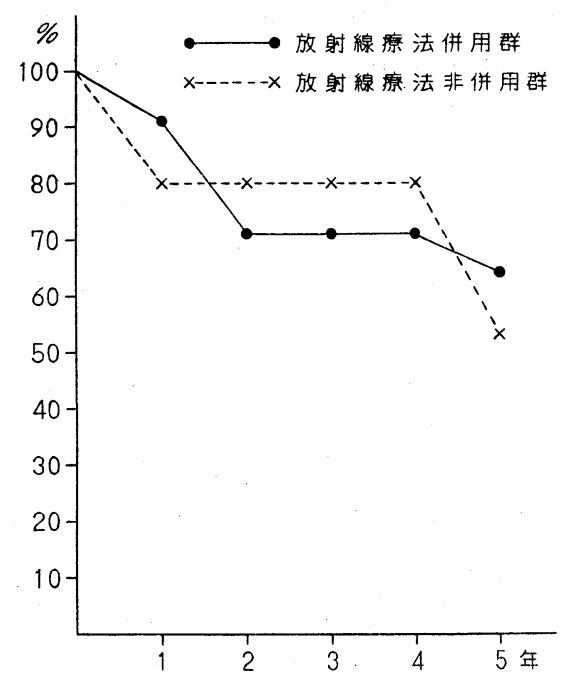

の56\%，35\%，23\%に比べて著しくよい成績であつた （表10，図8）。また stage IVの 7 例では，放射線療法 併用は 1 例のみで, 非併用群 6 例の成績と比較すること は無理であつた。

以上の成績より，腎細胞癌の治療としては，腎摘出術 と同時に放射線療法を併用した方が良好な生存率が得ら れること，またその効果は stage II 拉よび吕の症例に 扣いて顕著であること, しかし化学療法をさらに併用て ても,よりよい生存率は期待出来ないといら結果が得ら れた.

2）化学療法併用之生存率

腎摘出術と同時に化学療法を行なつた 38 例の 1 年生存 率は74\%，3 年生存率54\%，5年生存率は $49 \%$ で, 非併

表10 stage II， III の症例に打ける放射線療法併用 の有無と生存率 (\%)

\begin{tabular}{c|c|c|c|c|c}
\hline & 1 年 & 2 年 & 3 年 & 4 年 & 5 年 \\
\hline 放射線療法(+) & 81 & 60 & 53 & 53 & 53 \\
\hline 放射線療法(-) & 56 & 46 & 35 & 23 & 23 \\
\hline
\end{tabular}

図 8 stage II， IIIの症例における放射線療法併用 の有無と生存率

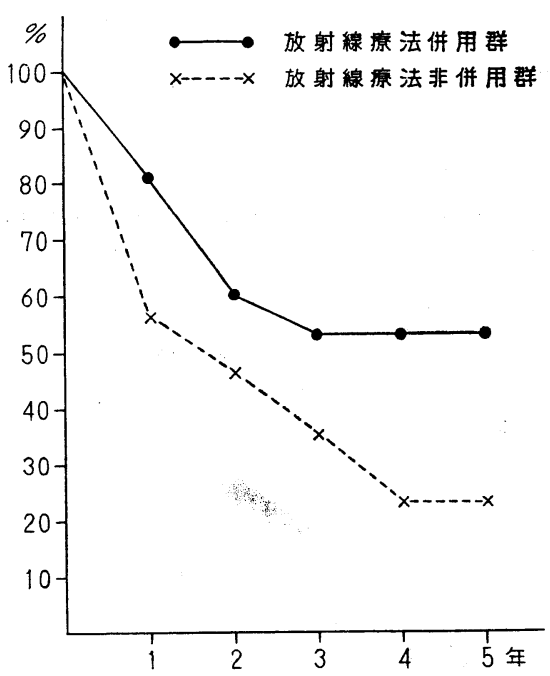

用群 27 例の生存率が 1 年 $73 \% ， 3$ 年56\%，5年50\%であ るのと比べて, 特に差はみられない（表11，図9）.

これを stage 別にみると, stage I の25例では, 化学 療法併用群17例 の 1 年, 3 年, 5 年生存率は $83 \%, 70$

表11 化学療法併用の有無と生存率（\%)

\begin{tabular}{c|c|c|c|c|c}
\hline & 1 年 & 2 年 & 3 年 & 4 年 & 5 年 \\
\hline 化学㙩法 $(+)$ & 74 & 54 & 54 & 54 & 49 \\
\hline 化学療法(-) & 73 & 61 & 56 & 50 & 50 \\
\hline
\end{tabular}

図 9 化学療法併用の有無と生存率

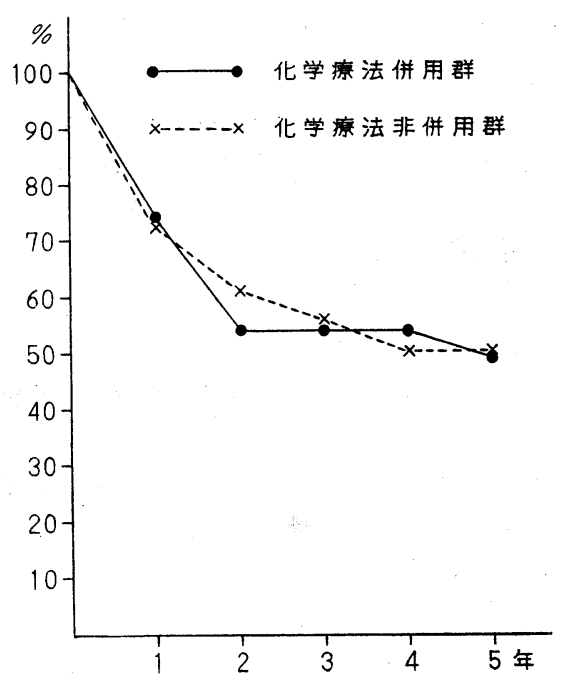


表12 放射線療法非施行群に扣ける化学療法併用の 有無と生存率 $(\%)$

\begin{tabular}{c|c|c|c|c|c}
\hline & 1 年 & 2 年 & 3 年 & 4 年 & 5 年 \\
\hline 化学療法(+) & 60 & 49 & 35 & 35 & 18 \\
\hline 化学療法(-) & 52 & 52 & 41 & 31 & 31 \\
\hline
\end{tabular}

図10 放射線療法非施行群における化学療法併用の 有無と生存率

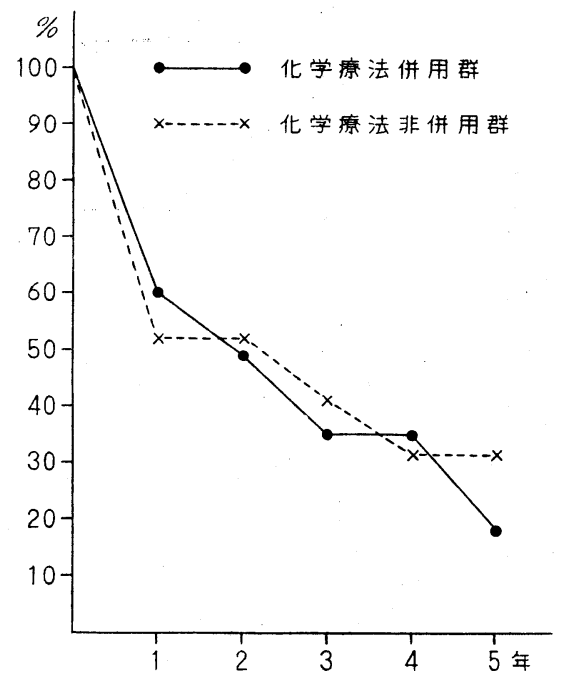

表13 放射線療法非施行群における化学療法併用の 有無之 stage 別例数

\begin{tabular}{c|c|c|c|c}
\hline & I & II & III & IV \\
\hline 化学療法(+) & 2 & 2 & 2 & 4 \\
\hline 化学療法(-) & 2 & 5 & 2 & 2 \\
\hline
\end{tabular}

$\% ， 61 \%$ であるのに対し，非併用群 8 例の 1 年生存率は $87 \% ， 3$ 年打よび 5 年生存率は $60 \%$ とほぼ同様の成績で あつた.つづ゙ stage II 抢よびIII 33 例についてみる と, 併用群 16 例の 1 年生存率 $67 \%, 3$ 年および 5 年生存 率33\%で，非併用群17例の $75 \% ， 59 \% ， 52 \%$ より生存率 は不良であつた。

以上の成績を検討する場合，同時に施行した放射線療 法の効果，影響を考慮しなければならない，特に stage II 抢よび III 症例では，先にのべたように，放射線療法 の効果が著しいことから, 上記の成績には放射線療法併 用の有無が関与しているものと考兄られる，そこで放射 線療法を行なつていない21例について，化学療法併用の 有無により生存率を検討した。化学療法併用群 10 例の 1
年生存率 $60 \% ， 3$ 年生存率 $35 \% ， 5$ 年生存率 $18 \%$ である のに対し，非併用群 11 例のそれは $52 \% ， 41 \% ， 31 \% て ゙$, 化学療法併用群によりよい生存率は認められなかつた (表12, 図10).な抗この両群の stage 別分類は表13の ごとくで, 化学療法併用例に stage IVの症例がやや多く 含まれて拈り，このことが両群の生存率に影響を与えて いることも考光られた。

\section{考按}

腎細胞癌の予後を支配する因子としては，治療法のほ かに性別，患側，症状とその持続期間，腫瘍の大きさ， 細胞型, 組織学的覀性度, 静脈への浸潤, 腫瘍の進行度 （stage）などがあげられる。したがつて腎細胞癌に対す る手術術式や，放射線療法拉よび化学療法併用の効果を 評価する場合には，これら他の因子との関連を考慮した 上での詳細な分析が大切である。しかし，そのためには 多数の症例を対象とした検討が必要であり, 自験例82例 では決して十分なものではない，そこでわれわれは，こ れら諸因子のらち, 予後に最も関与すると考兄られる stage との関連に热いて, 治療効果を検討した.

腎細胞癌の腎摘出術としては，一般に経腰式，経腹膜 式および経胸腹式の 3 つの到達法が施行されている。自 験例で経胸腹式腎摘出術を行なつたのは 2 例のみである ので，前 2 者について生存率を比較検討した．その結果 stage II 拉よび III 症例では, 術後 3 年以後は両者に差 を認めながたが， 1 年扰よび 2 年生存率は, 経腹膜式 腎摘出術の方が 経腰式腎摘出術より 良好な成績であつ た。

一方われわれの経験では，腎静脈への腫汮浸潤のある 例の予後は，浸潤のみられない例に 比べて 不良である が，その大きな影響は術後 2 年亡でであつた $b^{3)}, 508$ 例の腎細胞癌の 10 年以上に亘る予後観察から， 静脈浸潤が予後に大きな影響を与えるのは 2 年までであ り，それ以後は組織の悪性度がより関与するといつてい る.したがつて, 経腹膜式腎摘出術の 1 年拉よび 2 年生 存率が，経腰式のそれよりも良好であつたことは，経腹 膜式腎摘出術の長所である腎茎血管の処置を最初に行な うことにより，腫瘍細胞の血行性転移をある程度防止す ることが出来得たためとも考えられる.

腎細胞癌の腎摘出術に際して念頭に扣くべき原則は， 腎の剥離を行なら前に腎茎血管の結紮をるず施行するこ とと，腎とともに腎周囲脂肪織，Gerota の䇗膜および 腎門部と近傍のリンパ節などを摘出することである。わ れわれはまず腎茎血管の処理を行なつて，腫瘍細胞の氒。 
行性転移を防止することを第一に考兄, 従来は経腹膜式 腎摘出術を主に行ない上述の成績が得られた。しかし， 本法は腎上極を直視下に剥離することがやや困離な場合 があり，したがつて腫瘍が大きい時，特に腎上極が腫大 している場合の手術操作が難しい欠点がある。これに対 して, 経胸腹式腎摘出術は視野が最も広く, 腎を剥離 する前に腎茎血管を処理できるうえに, 横隔膜直下の部 分の豩離や切除を直視下に行ならことが可能で, 上述の 手術の原則を完全に実施し得る術式であり，最近はわれ われも”多用している。欧米でも Robson ${ }^{1)}$, Middleton ${ }^{4)}$ は根治的な経胸腹式腎摘出術を行ない, 治療成績の向上 を得ている.しかし腫瘍が小さいもので, 特に下極に生 じた例は, 経腹膜式到達法で十分と考兄る.

腎摘出術を施行し得なかつた13例の転帰は非常に不良 であるが，これらは high stage の症例が大部分で，そ のらち 7 例は遠隔転移を有する stage IVであうた。こ れら遠隔転移を有する症例に対する治療方針として，わ れわれは腎摘出が可能であれば積極的に行なら方針をと つている．それは孤立性の転移に対しては，同時に転移 巣の摘出または放射線療法をすることにより，明らかに 生存成績の改善が得られ，いつぽう多発性の転移例で は, 生存期間の延長は認められないが, 腎摘出は疼痛, 血尿, 発熱などの症状に対して有効なためである。また まれではあるが転移巣の自然消退が期待できるし，さら にホルモン療法, 化学療法の 効果を高めらると考兄る からである。しかし手術による死亡率が $4.3 \%$ あると より，むりな腎摘出術はさけるべきであるうし，とくに 多発性の転移例に対しては, 腎摘出に固執してはならな いと考えている5).

腎細胞癌に対する放射線療法については, Riches ${ }^{6)}$ が 腎摘出後に併用し，その生存率を高めたことを報告して 以来, その有効性が認められてきて抢り, Flocks ${ }^{7}$, Bratherlon ${ }^{8)}, \mathrm{Raffa}^{9)}$ らは術後照射例の 5 年抢よび 10 年生存 率が改善されたとのべている。しかしいつぽう, 放射線 療法は無効との意見 ${ }^{10)}$ もり, Finney ${ }^{11)}$ は100例の経験 から，術後放射線法は価值がないといつている。また Werf-Messing ${ }^{12)}$ は3,000rads の術前照射を行ない,ど の stage でも 5 年生存率の改善は久られなかつたが, stage $\mathrm{P}_{2}$ 抢よび $\mathrm{P}_{3}$ の症例では, 腫煌をとり残す頻度 が明らかに減少したといつている。

われわれの成績では， stage Iすなわち腫瘍が被膜内 に限局している例では, 放射線療法の併用効果はみられ なかつたが，腫瘍が腎被膜外または腎静脈内に浸潤して
いる stage II 括よび症例では，明らかに生存率の 改善が認められた。したがつて術後放射線治療は，腫瘍 が腎被膜の外飞浸潤している例や，所属リンパ節および 腎静脈に浸潤している場合に，5,000６,000 rads 照射 すべきであろう。

また最近の 13 例には $3,000 \sim 4,000 \mathrm{rads} の$ 術前照射を 行なつている。その目的は手術時に括壮る転移の予防, ならびそ腫瘍を縮小させ, 腎周用脂肪織内の怒張血管を 萎縮させて手術を容易にし，時には手術不能の症例を手 術可能にしょうとするものである. 自験例でも, 腎被膜 外への浸潤が高度で可動性の 全く認められなかつた例 に, 4,000rads の照射を行ない, 腫場の縮小とともに可 動性がみられるようになり, 周囲との境界も明らかにな つて, 腎摘出術が比較的容易に行なわれた例がある ${ }^{13)}$. Malken ${ }^{14)}$ む6 週間, 5,000rads の術前照射により, 腫 瘍の縮小と下大静脈内の腫瘍栓塞の著しい減少を認め, 根治的な腎摘出術を行ない得た例を報告している。

術前照射量について Riches ${ }^{15)}$ は, 腎茎周囲の肥厚を さけるために3,000rads がよいといい，Vaeth ${ }^{16)}$ は 5 週 間で 4,000 rads の照射を行なつている. また照射終了後 より手術までの待期期間について, Riches ${ }^{15)}$ は 3 週間, Vaeth $^{16)}$ は $4 \sim 6$ 週間がよいといつている.われわれは 13例に3,000〜4,000rads の術前照射を行なつた後 $4 \sim 22$ 日，平均10日後に腎摘出術を施行したが，全例とも腎䒱 の処理を含めて特に困離は認められなかつた。

腎細胞癌に対する化学療法として, 最近 Merrin ${ }^{17)}$ は, 進行性腎細胞癌44例に CCNUを単独怙よび vinblastine と併用して用い, CCNU 単独投与では $30 \%$, vinblastine との併用では60\%に自覚的または他覚的改善を認 めたといらている.しかし一般的には, 腎細胞癌の化学 療法は現在のところ悲観的である. Woodruff ${ }^{18)}$ は進行 癌270例に35種類の化学療法を行ない, 他覚的改善の及 られたのは10\%であるといい，Talley ${ }^{19)}$ も種々の化学 療法を施行した117例中, 効果のみられたのは velban を 使用した 2 例のみであつたという.

いつぽう腎摘出術に併用した抗癌剤の効果について， 阿兽 ${ }^{20}$ は赤沈が 1 時間 $30 \mathrm{~mm}$ 以上に六進している例で は，腎摘出の夕施行した例に比べて化学療法併用群はす ぐれた予後がえられたが，その効果は放射線療法併用例 に怙よばないといつている。

われわれの成績では, thio-Tepa, mitomycin C 単独, あるいは mitomycin C, 5-fluorouracil, cytosine arabinoside の三敵併用による化学療法併用群と, 非併用群との 
間に，生存率の差はみられなかつた。また stage 別にみ ても, 抗癌剤使用により生存率の明らかな改善は認めら れなかつた。さらに腎摘出術と同時に放射線療法および 化学療法を行なつた28例の検討でも，放射線療法併用に より明らかに生存率の改善がみられたが，さらに化学療 法を併用してもよりよい生存率はえられなかつた。

しかしわれわれは腎細胞癌の治療については，腎摘出 と同時に放射線療法を行ならことにより局所再発を抑制 し,ささら化学療法併用によつて全身性転移を防止する ことが大切であると考えている．したがつて今後は，腎 細胞痁により感受性のある抗癌剤の選択，投与量，併用 療法，投与形式，投与期間などについて検討し，ょりよ い、治療成績をあげたいと考える。

\section{結語}

㱟細胞癌82例について，その治療法と生存率，とくに 腎摘出術術式と放射線療法および化学療法併用の効果に ついて検討した。

1）全 82 例の 3 年生存率は $44 \% ， 5$ 年生存率は $39 \%$ で 西つた。このらち腎摘出術を施行し得た 69 例の 3 年およ び 5 年生存率は $50 \% ， 46 \%$ であつた。

2）腎摘出術を施行した69例の術式は，経腹膜式腎摘 出術が47例，経腰式腎摘出術が20例，経胸腹式腎摘出術 が 2 例であつた。

手術術式が最も問題となる stage II および III の33例に ついて，手術術式と生存率を検討すると，経腹膜式腎摘 出術施行群 25 例の生存率は, 経腰式腎摘出術を行なつた 8 例に比べて, 術後 2 年までは良好であつたが， 3 年以 後は両術式に差を認めなかつた。

3）放射線療法は31例に4,000 6,000rads の術後照射 を，13例に3,000〜4,000 rads の術前照射を行なつた。こ れら放射線療法併用群44例の 生存率は, 非併用群21例 のそれに比べて明らかに良好であつたが，その効果は stage II および III 症例に顕著であつた。しかし化学療 法をさらに併用しても，よりよい生存率はえられなかつ た。

4）化学療法としては, 初期の 3 例には thio-Tepa 5〜10 mg を10〜20可，10例には mitomycin C 2〜4mg を10〜20回投与したが，その後の25例には mitomycin C
2 4 $4 \mathrm{mg}$, 5-fluorouracil $250 \sim 500 \mathrm{mg}$, cytosine arabinoside $20 \sim 40 \mathrm{mg}$ の三剤を手術後より週 2 回，合計 10 回投 与した。

これら化学療法併用群38例と, 非併用群27例の生存率 は同程度で, ぞの stage でも, 化学療法併用により生 存率の改善はみられなかつた。

\section{文献}

1) Robson, C.J., Churchill, B.M. and Anderson, W.: Trans. Amer. Ass. G. U. Surg., 60, 122 , 1968.

2) 南武, 增田富士男, 佐々木忠正：日泌尿会 誌, 66, 474, 1975 .

3) Myers, G.H. Jr., Fehrenbaker, L.G. and Kelalis, P.P.: J. Urol., 100, 420, 1968.

4) Middleton, R.G. and Presto, A.J. III.: J. Urol., $110,36,1973$.

5）増田富士男，佐々木忠正，菱沼秀雄，荒井由 和, 小路 良, 陳 瑞昌, 町田豊平: 泌尿紀 要, 23, 135, 1977.

6) Riches, E., Griffiths, I.H. and Thackray, A.C.: Brit. J. Urol., 23, 297, 1951.

7) Flocks, R.H. and Kadesky, M.C.: J. Urol., 79, 196, 1958.

8) Bratherton, D.G.: Brit. J. Radiol., 37, 141, 1964.

9) Raffa, S.: Cancer, 25, 26, 1970.

10) Robson, C.J.: In current controversies in urologic management, Scott, R. Jr., p. 33, Saunders Co., Philadelphia, 1972.

11) Finney, R.: Brit. J. Urol., 45, 258, 1973.

12) Werf-Messing, B.: Cancer, 32, 1056, 1973.

13) 増田富士男, 南 孝明, 南武 : 泌尿紀要, 17, 57, 1971 .

14) Malken, R.B.: J. Urol., 114, 782, 1975.

15) Riches, E.: In current controversies in urologic management, Scott, R. Jr., p. 38, Saunders Co., Philadelphia 1972.

16) Vaeth, J.M.: Cancer, 32, 1053, 1973.

17) Merrin, C., Mittelman, A., Fanous, N., Wajsman, Z. and Murphy, G.P.: J. Urol., 113, 21, 1975.

18) Woodruff, M.W., Wagle, D., Gailani, S.D. and Jones, R. Jr.: J. Urol., 97, $611,1967$.

19) Talley, R.W.: Cancer, 32, 1062, 1973.

20）阿曾佳郎, 小磯謙吉, 岡田清己, 星野嘉伸, 村 橋勲：日泌尿会誌，65，209，1974.

（1977年 7 月 15 日受付） 